\title{
VIVENCIANDO UMA PANDEMIA
}

Carmen Lupi Monteiro Garcia ${ }^{1}$

https://orcid.org/0000-0003-1870-4829

Sou Enfermeira há 42 anos, profissão escolhida por ter vivenciado o "cuidado" dispensado a minha avó paterna acometida por câncer cerebral.

Sou Sanitarista, acredito na Saúde para Todos. Trabalhei em várias frentes na assistência e docência.

Jamais imaginei viver uma "Pandemia", que até então tinha apenas estudado quando ocupei os bancos das salas de aula da FIOCRUZ, no Rio de Janeiro.

Em isolamento social absoluto, por ser grupo de risco grave (por idade, artrite reumatóide ativa, câncer) , sinto-me culpada por não estar na linha de frente atuando junto aos colegas profissionais.

Encontro-me hoje estudando números, depoimentos, vídeos, normas, cartilhas, at4ndendo ex-alunos, confortando colegas, divulgando informações, participando de grupos técnicos sobre COVID 19.

Assisto a Enfermagem sair da invisibilidade social, porém constato a falta de condições de trabalho a que os profissionais estão submetidos.

Observo nas redes sociais que muitos profissionais entraram nas discussões políticas defendendo "a" ou "b", em vez de contribuírem tecnicamente para o avanço da profissão e proteção dos profissionais que estão terrivelmente desgastados na linha de atuação.

Acredito na Ciência e na construção de Políticas Públicas para a Saúde, por isso me dediquei por muito tempo na construção do Sistema único de Saúde-SUS.

Observo o esforço das entidades representativas da profissão contribuindo com propostas técnicas, orientações, normativas, compras emergenciais de equipamentos de proteção individual para os profissionais, ocupando a mídia nacional e projetando a Enfermagem.

O que me deixa estarrecida é constatar o número de profissionais acometidos e o número de mortos em todos os continentes. Deparei-me com ex-alunos que exerciam a profissão na Itália e nos Estados Unidos, que foram a óbito, cujas mães me deram a notícia. E foram dias de muita tristeza para digerir tais fatos, porque em seguida constato mortes de pessoas próximas sem que nada eu possa fazer.

Enquanto isso, assisto mudanças nos rumos políticos em detrimento dos avanços técnicos no avanço da Pandemia, e me pergunto como os profissionais de saúde ficarão nesta guerra?

Hospitais lotados, falta de leitos e equipamentos de proteção individual-EPI, péssimas condições de trabalho por instalações inadequadas e improvisadas, e o mais terrivel, o acometimento de profissionais pelo Corona, desfalcando as equipes de trabalho.

A Enfermagem que está presente nas 24 horas na linha de frente da pandemia, já constata várias baixas e inúmeros afastamentos.

Termino com alguns questionamentos que ainda não consigo vislumbrar respostas:

- Nos tornamos visíveis de fato?

- Sairemos mais fortes depois da pandemia?

- Teremos uma profissão socialmente reconhecida?

- Não é por acaso que 2020 é o ano da Enfermagem?

- Conseguirei presenciar a Enfermagem que merecemos?

Descritores: Enfermagem; Pandemias; Virus da SARS; Infecções por Coronavírus.

\section{Experiencing a Pandemic}

Descriptors: Nursing; Pandemics; SARS virus; Coronavirus infections.

\section{Experimentar una pandemia}

Descritores: Enfermería; Pandemias; Virus del SRAS; Infecciones por coronavirus. 